\title{
Smallholder Farmers' Decision to Participate in Vegetable Marketing and the Volume of Sales in West Shewa Zone of Oromia National Regional State, Ethiopia
}

\author{
Aman Rikitu ${ }^{1}$, Bezabih Emana ${ }^{2}$, Jema Haji ${ }^{3}$ \& Ketema Bekele ${ }^{3}$ \\ ${ }^{1}$ Haramaya University, Ethiopia \\ ${ }^{2}$ General Manager HEDBEZ Business \& Consultancy PLC. P.O.Box 15805, Addis Ababa, Ethiopia \\ ${ }^{3}$ Haramaya University, College of agriculture and environmental science, Ethiopia \\ Correspondence: Aman Rikitu, Haramaya University, Ethiopia. E-mail: aman.rikitu@ gmail.com
}

Received: May 20, 2019 Accepted: June 6, 2019 Online Published: September 23, 2019

doi:10.5539/sar.v8n4p48 URL: https://doi.org/10.5539/sar.v8n4p48

\begin{abstract}
This study examines vegetable producers' market participation and sales volume using cross-sectional data obtained from 385 randomly and proportionately sampled households from West Shewa zone, Oromia region of Ethiopia. Heckman two-step procedure was used to analyse the determinants of participation in vegetables markets and volume of sales during the study period. Probit model shows that education level, distance to nearest market, access to irrigation, use of pesticide and participation in any civic organization significantly affect market participation decision. Further, results from ordinary least squares regression show that sex of household head, land size, distance to farmer training centre, access to irrigation, use of pesticide and participation in civic organization significantly affect the level of market participation of the farm households in vegetable markets. The findings imply that support for female households, improving adult based education, participation in civic organization, infrastructure, access to irrigation and improved inputs are a means to increase vegetable production market participation and sales volume in West Shewa, Ethiopia.
\end{abstract}

Keywords: vegetable market participation, Heckman two step procedure, OLS, probit, Oromia, Ethiopia

\section{Introduction}

Vegetable production is an important economic activity in Ethiopia, which ranging from gardening smallholder farming to commercial state and private farms (Bezabih et al., 2015). It is taken up about $1.44 \%$ of the area under all crops at national level and contributes $2.14 \%$ of the total volume of crops produced (CSA, 2016). It is an efficient way to address poverty alleviation, take care of the health and well-being of the consumers, and offers new market opportunities for farmers, consumers, and agro-industry (Cochrane and Bekele, 2018; Chala and Chalchisa, 2017). Vegetable production is integrated into mixed farming system where different types of crops are produced on the same plot of land or in sequence with other crops in rotation (Nimona, 2017). Depending on availability of land and crop suitability for intercropping, some vegetables are grown either as sole or intercropped with other vegetables or cereals. Vegetables such as tomato, potato, beetroot, carrot, cabbage, onion, sweet potato and hot pepper are dominantly grown in Ethiopia. From these vegetable production tomato, potato and onion are the major vegetables production of West Shewa zone (WSZIAO, 2017). Integrating vegetable production in a farming system has contributed substantially to food and nutrition security as the vegetables complement stable foods for a balanced diet by providing vitamins and minerals (Gani and Adeoti 2011; Afari-sefa and Dinssa, 2015).

Improving farmers' participation in markets is a vital determinant of prosperity and advancement (Getachew and Bamlak, 2014; Masuku et al., 2014). In many rural areas, vegetable market participation plays a crucial role in generating better income and enhancing the welfare of smallholder farmers and thus contributes to their livelihoods. Successful market developments for products with a relatively large demand and widely traded commodities, may lead to the "adding up" effect, with market potential being exaggerated by the "strong interest from the side of market participants"(Moono, 2015; Musah et al., 2014; IMF, 2015).

The vegetables market system is often considered inefficient in Ethiopia in general and in West Shewa in 
particular (Chala and Chalchisa, 2017). As a result, smallholder farmers find it difficult to dispose their produce at attractive price and places of their choice due to perceived weaknesses in vegetable marketing system. This negatively affects vegetable farmers' motivation to invest in vegetable production and meet the demands of consumers, hence decrease in farm income (Chittora et al., 2017). Smallholder farmers effective market participation are the right pathway of pulling rural people out of food insecurity (FAO, 2016; Montalbano, 2017). Therefore, the need to improve to farmers' livelihood through market participation which generates employment for farm workers and others, leveraging economic growth is very crucial.

Price information is the basic requirement of any marketing activity. Imperfections in markets and asymmetric market price information impede the potential gain that could have been accomplished under the presence of business sectors with complete data (Nakasone, 2014). Both buyers and sellers usually do not have the same level and type of market information on the vegetable prices at the central market (Hjalmarsson, 1978; Fried et al., 2004; Beneberu et al., 2016). In addition to this, except in some the price of vegetable products is set by the traders which highly discourage the producers (Nakasone, 2014; Pierre et al., 2017). Not only price, but also lack of agricultural inputs such as land, fertilizer, and improved seeds are the major factors that affect the production of vegetables. When farmers face these limitations, their objectives to produce fore market will be affected.

Unlikely, very little research has been done on market participation and volume marketed of vegetable farmers in Ethiopia in general and in West Shewa in particular. This work is an endeavour to fill this research gap and adds to the age of proof for producers to acknowledge the vital role that participation in market for farmers in study area. It is important to carry out such analysis in West Shewa where population growth and declining farm size are becoming serious challenges (Wickramasinghe et al., 2009). Therefore, it is necessary to analyze vegetables (tomato and potato) farmers' market participation and level of participation in West Shewa zone. Along these lines, the investigation might produce on the concurrent communication of family choices of market participation and the most affecting elements of the market support of smallholder farmers in West Shewa.

\section{Methodology}

\subsection{Description of the Study Area}

The study was conducted in west Shewa zone, which is one of the 19 zones of Oromia National Regional State of Ethiopia. It is bordered on the south by the Southwest Shewa zone and the Southern Nations, Nationalities and Peoples Region, on the southwest by Jimma zone, on the west by East Wollega zone, on the Northwest by Horo Guduru Wollega, on the North by the Amhara Region, on the northeast by North Shewa, and on the East by Oromia Special Zone Surrounding Finfinne. Its highest elevation is at Mount Wanchi (3,386 meters above sea level); other notable peaks include Mount Menagesha and Mount Wachacha. West Shewa zone is administratively divided into 22 districts and one urban town (Ambo) which is the main urban centre of the zone. There are 590 kebeles of which 532 are rural and 58 are urban kebeles (WSZPEDO, 2009).

West Shewa zone is located at $8^{\circ} 17^{-} 8^{\circ} 57^{\prime} \mathrm{N}$ latitude and $37^{\circ} 08-38^{\circ} 07^{\prime} \mathrm{E}$ longitudes, within altitudes ranges of 1050-3500 m.a.s.l. It has annual average rain fall of $1,115 \mathrm{~mm}$. The mean maximum and minimum temperatures are $11.7^{\circ} \mathrm{C}$ and $25.4^{\circ} \mathrm{C}$, respectively. Areas beyond 2,300 meters above sea level fall within the highland climatic Zone, and areas between the 1,500-2,300 meter above sea level contour fall within the midland climatic zone; and areas below 1,500 contour fall within the lowland or hot climatic zones. The Dega, Woina-Dega and Kolla agro-ecological zone $27 \%, 56 \%$ and $17 \%$ of the total area of the zone, respectively. This Zone has a total population of 2,327,845, of whom 290,282(12.47\%) are living in towns and 2,037,563 (87.53\%) are living in rural area which are highly dependent on agriculture. The total land area of this zone is 1,434,929 ha which accounts for about $4.15 \%$ of Oromia region's total land area. Land uses in the locality included cultivation, grazing and forest with areas 880,211 ha (61.34\%), 249, 645 ha (17.39\%) and 104,799 ha (7.3\%) respectively. In terms of topography, it has flat land (47.7\%), up-down (25.7\%), mountain (16.8), valley (4.6) and others (5.2\%). About $87.53 \%$ of the population are dependent on agriculture. Out of the all vegetable production (Potato, sweet potato, onion, tomato, cabbage, carrot, green paper, and so on.) collected in the year 2016/17 in this zone were 9,957,730Q (WSZIAO, 2017). 


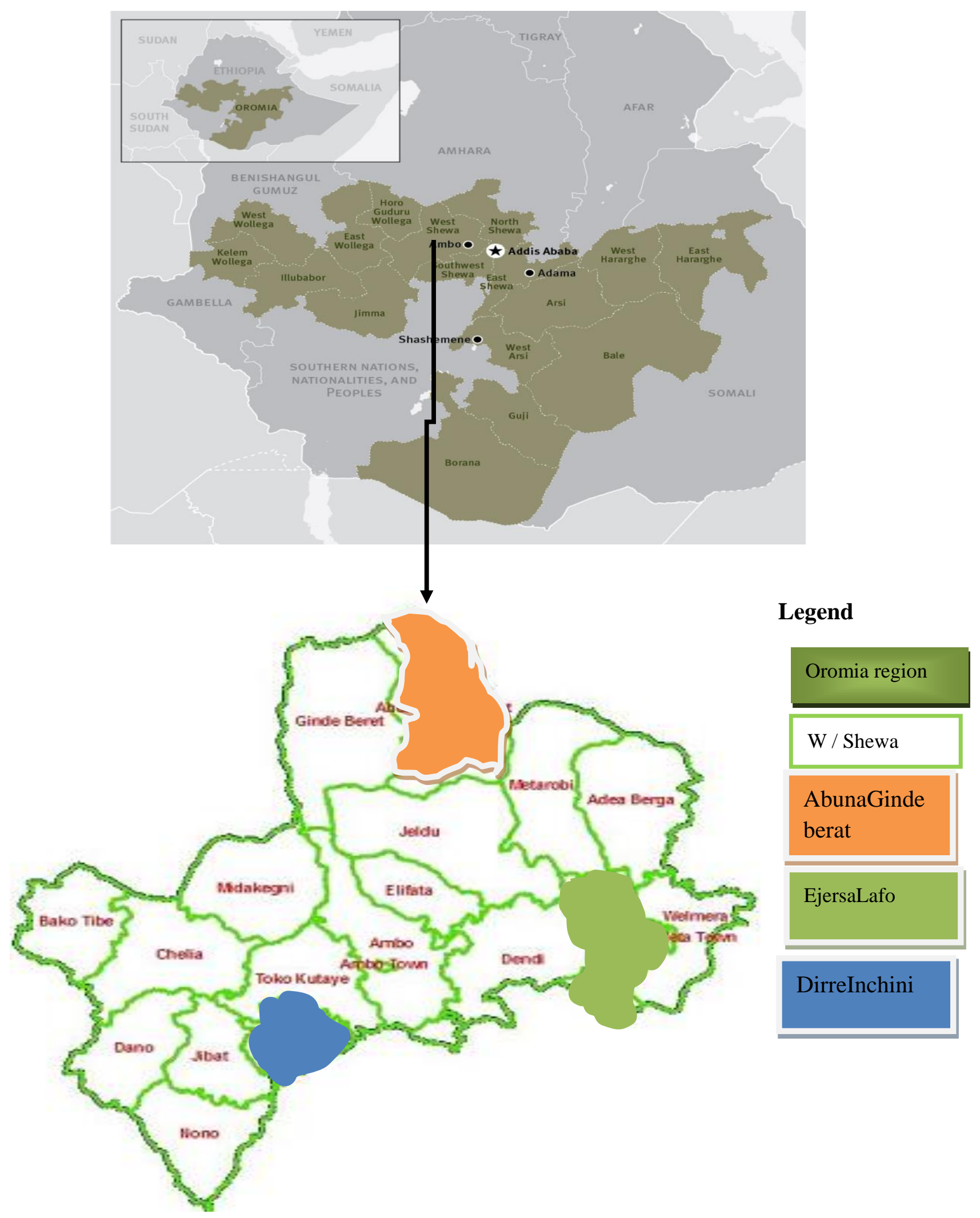

Figure 1. Geographical location of the study area 


\subsection{Sampling Techniques and Data Collection}

\section{2. 1. Methods of Data Collection}

The study was conducted in Abuna Gindeberat, Dire Inchini and Ejersa Lafo districts of West Shewa zone of Oromia region. Both quantitative and qualitative data were gathered and used in the study. In order to generate the required data, both secondary and primary data sources were used. Primary data sources include smallholder farmers, zonal and districts Agricultural and Rural Development Offices, zone and district Irrigation Development Authority. Secondary data such as: reports of line ministries, journals, books, CSA and internet browsing, national policies, zone and district reports, among others were also used to augment primary data.

\subsubsection{Sampling Method}

A multi-stage random sampling procedure was used for this study. In the first stage, zone was stratified into three groups based on agro ecologies. In the second stage, three districts were randomly selected from nineteen districts (four highlands, seven midlands and eight lowland) ecologically stratified districts where major smallholder vegetable crop producers exist. In the third stage, nine kebeles were randomly selected from the stratified and randomly selected districts. Finally, 385 households, equation (1) from nine Kebeles were selected using simple random sampling with probability proportional to size during 2018 (table 1).

$$
N=\frac{Z^{2} p q}{e^{2}}
$$

Where, $\mathrm{N}$ is the sample size, $\mathrm{Z}^{2}$ is the abscissa of the normal curve that cuts off an area $\alpha$ at the tails $(1-\alpha$ equals the desired confidence level, e.g., 95\%), e is the desired level of precision, $\mathrm{p}$ is the estimated proportion of a participant that is present in the population, and $q$ is 1-p. The value for $\mathrm{Z}$ is found in statistical tables which contain the area under the normal bell-shaped curve. With the assumption of there is a large population but that we do not know the variability in the proportion that were adopt the practice; therefore, assume $\mathrm{p}=0.5$ (maximum variability). Furthermore, suppose we desired a $95 \%$ confidence level and $\pm 5 \%$ precision. a sample of 385 farm household heads were selected from nine kebeles using random sampling with probability proportional to size as shown in Table 1.

$$
N=\left(\frac{1.96^{2}(0.5)(0.5)}{0.05^{2}} \approx 385\right)
$$

Table 1. Distribution of sample farm households by districts and kebeles

\begin{tabular}{lllll}
\hline Selected district & $\begin{array}{l}\text { Total No of vegetable } \\
\text { producers in the district }\end{array}$ & $\begin{array}{l}\text { Sample size } \\
\text { per district }\end{array}$ & Selected kebeles & $\begin{array}{l}\text { Sample size } \\
\text { per kebeles }\end{array}$ \\
\hline Abuna Gindeberet & 110,000 & 184 & Gutosembo & 57 \\
& & & Haro & 79 \\
& & & Walensu & 68 \\
Dirre Inchini & 74,698 & 125 & Arfinjo & 49 \\
& & & BiloAbayi & 45 \\
& & & Bola Damaka & 31 \\
Ejersa Lafo & 45,895 & 76 & Chalalaka & 24 \\
& & & GololeKiltu & 27 \\
& & & SemboGoro & 25 \\
Total & 296,593 & 385 & & 385 \\
\hline
\end{tabular}

Source: Own surveyed data 2018

\subsection{Data Analysis Method}

Both descriptive statistics and econometric model (Heckman two-step) were employed to analyze data.

\subsubsection{Descriptive Statistics}

This method of data analysis refers to the use of percentages, mean, standard deviation, t-test and $\chi^{2}$-test in the process of examining and describing household characteristics and compares market participant and non-participants in terms of these characteristics. 


\subsubsection{Econometric Analysis}

Heckman two-stage econometric model was used to identify factors affecting farmers' participation decision in vegetable markets and the volume of vegetable products supplied to the market. Under a semi-commercial system, where both marketing and home consumption are playing a central role in production decision, all crops produced by a household may not be marketable surplus. Most recent literature (Imai, 2012; Bogale and Bogale, 2005; Andrew, 2007) adopted Heckman's two stage model to identify factors that affect producers' participation in output markets and also identify the factors that determine the level of output supplied to market. The Heckman model is useful for handling linear regression models when there's a selection mechanism at work i.e. once the result equation involves never-ending variable. However, we tend to are usually interested by cases wherever the result equation involves a divided variable. In effect, we would have a probit choice equation and a probit outcome equation (Frederick, 1983).

Generally, Tobit model has the problem of assumption. It assumes the same set of parameters and variables to decide both the probability of market participation and the level of participation. Due to this assumption, the same variables in the same way introduce consistency bias in the model. Hence, Heckman two stages was employed in this study to minimize this problems. The model was comprised of two steps; firstly, choice condition was evaluated by utilizing a probit model and also, a result condition was evaluated by using OLS regression. A probit model predicts the likelihood of whether the individual participates in the vegetable market or not:

$$
p_{r}\left(z_{i}=1 / \omega_{i}, \alpha\right)=\left(t\left(\omega_{i}, \alpha\right)\right)+\varepsilon_{i}
$$

Where $Z_{i}$ is an indicator variable equal to unity for farmers participating in vegetable market, $\varphi$ is the standard cumulative distribution function, $\mathrm{w}_{\mathrm{i}}$ is factors affecting decision to participate in vegetable market $\alpha$ is the vector of coefficient to be estimated and $\varepsilon i$ is normally distributed disturbance term with mean zero and variance $\delta^{2}$. The variable $Z_{i}$ takes the estimation of 1 if farm household i participate in vegetable market and zero otherwise.

$$
z_{i}^{*}=\alpha \omega_{i}+u_{i}
$$

Where $Z_{i}^{*}$ is the idle dimension of utility the small scale vegetable farmers get from market participation, $\sim \mathrm{N}$ $(0,1)$ and,

$$
\begin{gathered}
z_{i}=1 \text { if } z_{i}^{*}>0 \\
z_{i}=0 \text { if } z_{i}^{*} \leq 0
\end{gathered}
$$

Heckman models incorporate exclusion restrictions to compute an adjustment factor Inverse Mills Ratio (IMR) which included in the second-stage estimation in OLS part of this model. The IMR is figured as:

$$
\frac{\varphi\left(h\left(\omega_{i}, \hat{\alpha}\right)\right)}{\varphi\left(\omega_{i}, \hat{\alpha}\right)}
$$

Where $\varphi$ is the normal probability function. The second equation is given by:

$$
\mathrm{E}=\left(Y_{i} / Z=1\right)=f\left(x_{i}, \beta\right)+\lambda\left(\frac{\varphi\left(h\left(\omega_{i}, \hat{\alpha}\right)\right)}{\varphi\left(\omega_{i}, \hat{\alpha}\right)}\right)
$$


Where $\mathrm{E}$ is the desire administrator, $\mathrm{Y}$ is the (continuous) extent of vegetable sold, $\mathrm{x}$ is a vector of autonomous factors influencing the amount of vegetable sold, and $\beta$ is the vector of the comparing coefficients to be estimated. In this way, Yi can be explained as follows:

$$
y_{i}^{*}=\beta^{\prime} x_{i}+\gamma \lambda+u_{i}
$$

$y_{i}^{*}$ is only observed for those vegetable farmers who participate in the markets

Where $N\left(0, \delta_{u}\right) .(\mathrm{Zi}=1)$, in which case $Y i=Y i$.

The model would thus be evaluated as follows; in the first step of deciding whether to participate in vegetable market or not. This can be indicated as:

$$
\rho_{(0,1)}=\beta_{o} X_{O}+\beta_{1 X 1}+\ldots \ldots \ldots \ldots+\beta_{n} X_{n}+e
$$

Where 1 denoted participation and 0 non- participation, $\beta 0$ is a constant $\beta 1 \ldots . . n$ are parameters to be estimated $\mathrm{x}_{\mathrm{is}}$ are vector of explanatory variables.

In the second step OLS were estimated to test the effect of hypothesized factors on the level of participation measured by the amount of potato and/or tomato sales in the market (Frederick 1983).

The model is specified as;

$$
Y=\beta_{o} X_{O}+\beta_{1 X 1}+\ldots \ldots \ldots+\beta_{n} X_{n}+e
$$

Where $\mathrm{Y}$ denotes the volume of vegetable sold, $\beta_{o}$ is a constant, $\beta_{1} \ldots . . \mathrm{n}$ are parameters to be estimated $x_{i}$ xare vector of explanatory variables.

\section{Results and Discussion}

This chapter presents the results of the study and discusses results in comparison with the results of similar studies. It is organized under two sections; the first section deals with the description of demographic, socio-economic and resource allocation of the sample farmers using descriptive statistics. The second section identifies factors affecting farmers' participation in the market and the volume of sales using Heckman two-step model.

\subsection{Descriptive Statistics Results}

\subsubsection{Descriptive Statistics Result}

Table 2 shows that out of the total vegetable producers about 184(47.79\%) were vegetables market participant while 201(52.21\%) were non-market participants. As shown in Table 2 from the total market participants about $175(70.3 \%)$ were male headed households. Results show that $9(30 \%)$ of the female respondents were market participants while $175(70.3 \%)$ of male respondents were market participants. The results also shows that, 172 (48.45\%) of participants and 183(51.55\%) non participants have owned farm land. Furthermore, results show that $184(65.71 \%)$ of vegetable market participants have access to irrigation and about $96(34.29 \%)$ non-participants have access to irrigation. The results in Table 2 showed that, $83(46.89 \%)$ and $175(64.10 \%)$ of vegetable market participant farm households used fertilizer and pesticide for their vegetable production while $94(53.11 \%)$ and $98(35.90 \%)$ of non-market participants used fertilizer and pesticide for their vegetable production in the year 2018 production period respectively. The result also show that $183(82.06 \%)$ of vegetable market participants farm households participated to civic organization while 40 (17.94\%) of non-market participants farm households participated to civic organization. The $\chi^{2}$-test results showed that there is significant difference between participants and non-participants in terms of irrigation access, fertilizer and pesticide usage at $1 \%$ probability level. 
Table 2. Descriptive statistics of dummy variables

\begin{tabular}{|c|c|c|c|c|c|c|}
\hline \multicolumn{7}{|c|}{ Vegetable production } \\
\hline & & \multicolumn{2}{|c|}{ Market participants $(\mathrm{N}=184)$} & \multicolumn{3}{|c|}{ Non-market participants $(\mathrm{N}=201)$} \\
\hline Variable & & No. & $\%$ & No. & $\% \quad x^{2}$ & value \\
\hline Sex of HH & Female $=0$ & 9 & 30 & 21 & 70 & $4.12 * *$ \\
\hline Own land & Yes & 172 & 48.45 & 183 & 51.55 & 0.79 \\
\hline Irrigation water & Yes & 184 & 65.71 & 96 & 34.29 & $132.16^{* * *}$ \\
\hline Fertilizer & Yes & 83 & 46.89 & 94 & 53.11 & 0.10 \\
\hline Pesticide & Yes & 175 & 64.10 & 98 & 35.90 & $10.78 * * *$ \\
\hline $\begin{array}{l}\text { Participation to } \\
\text { civic organization }\end{array}$ & Yes & 183 & 82.06 & 40 & 17.94 & $249.46^{* * *}$ \\
\hline
\end{tabular}

Note: $* * *$ and $* *$ showed $1 \%$ and $5 \%$ significance level

Source: own surveyed data 2018

As indicated in Table 3, the average age of vegetable market participant sample household heads is 48.56 years with an average age of non-participants is 45.36 years. The difference in age of the sample household heads between participants and non-participants is statistically significant at 1 percent significance level. The average family size of the participant farm households was 7.13 while that of non-participants is 7.16 , which is higher than West Shewa zone where the average family size was 5 persons and Ethiopian average family size, which is 4.6 persons per-household (Zerfu, 2017).

As presented in Table 3, the average educational level in schooling years of the participant farm household heads is 6.15; while for non participant household heads is 3.78. This indicates that, on average the sample farm household heads attended the minimum (first cycle) education. On the other hand, non-market participant farm households have more farm experience than participant households. On average, non-market participant households have 14.72 years of farm experience while market participant farm households have 20.30 years average work experience with standard deviations of 1.03 and 0.75 respectively. The difference in farm experience between market participant and non-market participant is statistically significant at 1 percent significance level, while the difference in distance from household residence to local market between market participant and non-market participant of farm households' head was statistically significant at 1 percent significance level. The result in Table 3 showed that the average distance from the nearest market to vegetable market participant farm household heads were 0.55 walking hours with a standard deviation of 0.04 , while for those who were not participating in vegetables' market it takes 1.14 walking hours with a standard deviation of 0.04. The result also shows that the average distance from the nearest town to farm households' residence were 1.71 walking hours while for those non market participants farm household were 2.09 walking hours. Similarly, the average distance from farmer training centre (FTC) to vegetable market participant farm households were 0.75 walking hours, while for those none market participant were 1.01 walking hours. The average land allocated for vegetable production of market participants is 0.15 hectares with a standard deviation of 0.01 , while average land allocation of non-participants is 0.14 with a standard deviation of 0.04 .

Credit is an important factor to participate in the market. The average amount of credit obtained by participants is 797.28 Birr while non-participants obtained 889.43 Birr with standard deviations of 183.40 and 144.85 respectively. The average total livestock owned by vegetables market participants and non-participants were 11.33 TLU and 8.09 TLU with a standard deviations of 0.4765 and 0.3727 respectively. There is significant difference between participants and non-participants at 1 percent significance level. Generally, the average non/off- farm income of participant and non-participant farm households were 1462.87 Birr and 660.95 Birr with a standard deviations of 464.701 and 197.949 respectively. 
Table 3. Descriptive statistics of continuous variables

\begin{tabular}{|c|c|c|c|c|c|}
\hline \multicolumn{6}{|c|}{ Vegetable farmers } \\
\hline & \multicolumn{2}{|c|}{ Market participants(184) } & \multicolumn{3}{|c|}{ Non-market participants(201) } \\
\hline Variables & Mean & std. Dev & Mean & std. Dev & t-test \\
\hline Age of household head (Years) & 48.56 & 0.99 & 45.36 & 0.72 & $-2.65 * * *$ \\
\hline Family size & 7.13 & 0.20 & 7.16 & 0.20 & 0.14 \\
\hline Educational level of HH head & 6.15 & 0.28 & 3.78 & 0.24 & $-6.56 * * *$ \\
\hline Farm experience (Yrs) & 20.30 & 1.03 & 14.72 & 0.75 & $-4.45 * * *$ \\
\hline Distance from nearest market (hr) & 0.55 & 0.04 & 1.14 & 0.04 & $11.05^{* * *}$ \\
\hline Distance from major town (hr) & 1.71 & 1.07 & 2.09 & 0.98 & $3.54 * * *$ \\
\hline Distance from FTC $(\mathrm{hr})$ & 0.75 & 0.63 & 1.01 & 0.59 & $4.21 * * *$ \\
\hline Vegetable land size(ha) & 0.15 & 0.01 & 0.14 & 0.14 & -0.92 \\
\hline Amount of credit gained (Birr) & 797.28 & 163.40 & 889.43 & 144.85 & 0.42 \\
\hline Frequency of extension contact & 1.85 & 0.14 & 1.11 & 0.11 & $3.42 * * *$ \\
\hline Total livestock (TLU) & 9.83 & 0.51 & 9.79 & 0.39 & $-5.29 * * *$ \\
\hline Non/off-farm income (Birr) & 1462.87 & 464.70 & 660.945 & 197.75 & -1.64 \\
\hline
\end{tabular}

Note: $* * *$ showed $1 \%$ significance level

Source: Own surveyed data 2018

\subsection{Determinants of Market Participation Decision}

Heckman two-step model was used to determine the factors affecting farm households' market participation and level of market participation in vegetable marketing. The variables included in the model were sex of household head, family size, educational level, farm experience, frequency of extension contact, distance to farmer training centre, distance from market, distance to cooperative, amount of credit gained, land size, access to irrigation use, fertilizer cost, use of pesticide to vegetable, participation to civic organization, total income from cereal crop, total livestock unit of farm households and off/non farm income.

To identify factors affecting market participation of vegetable producers in the study area, a Probit model was estimated in the first step of the Heckman selection equation. The summary of model results was presented in Table 4. Accordingly, educational level, distance from cooperative, access to irrigation use, use of pesticide to vegetable and participate to any civic organization were found to significantly affect the farmers' decision to participate in the vegetable market. The Inverse Mills Ratio (IML/Lambda) term was significant and positive at less than 10 percent significance level, which suggests that the error term in the selection and primary equation are positively correlated. This implies that unobserved factors that make participation in vegetable marketing are more likely to be linked with higher scores on the dependent variable. Moreover, rho is positive which implies that unobservable factors are positively correlated with dependent variables (Table 4).

The educational level of the household head: This variable influenced the probability of market participation decision of the farm household's positively and significantly at 10 percent significance levels. The result in Table 4 confirmed that as farm household get better education level, his attitude toward market participation decision is positive. This is the fact that farm household with better education level has more marketing knowledge which encourage them to market participation than others. This result is in line with (Maponya et al., 2016; Osmani and Hossain, 2015; Omiti and Mccullough, 2009) which stated that as individual access more education he/she is empowered with the marketing skill and knowledge that will spur individual to participate in the market.

Distance to nearest market: This variable affected the market participation decision of the farm households' negatively and significantly at 1 percent significance level. Households living in locations far from markets are much less likely to participate in markets probable due to the fact of greater marketing costs. The studies conducted on these issues have agreed that marketing costs without delay expressed in phrases of distance from the market limits smallholder market participation. As it's known, most communities have small market around their residence, but face poor prices in those local/village markets. This implies that the farmer that lived at far distance from the local market had less chance to participate in the vegetable market. The problem is associated with the long distances farmers have to travel to reach markets that offer profitable prices (Byron, 2014; Mohamedl, 2014; Musah et al., 2014). Thus, households who reside far away from market places are expected to have lower output market participation or on the other hand households closer to market outlets are more likely to participate in marketing activities. 
Access to irrigation: As regression result in Table 4 indicated, this variable influences market participation decision significantly and positively. Irrigation removes some of the risks related with rainfall variability and extends the likelihood of using bought quality input due to the limited chance of crop failure. The probit regression result confirmed that farm households with access to irrigation are more likely to participate in vegetable markets compared to the others. The study by Barrett et al. (2011) confirmed that, farmers with access to irrigation enjoyed superior options on market participation, and therefore have a higher expected welfare level than do less well-endowed farmers. This implies that, households with had access to irrigation can produce more marketable production and had more chance to participate in market than other households.

Application of pesticide: As regression result of Heckman two-stage, application of pesticide affect the probability of market participation decision positively and significantly at 5 percent. The Heckman two-stage results presented in Table 4 indicate that, the probability of market participation of farmers who applied pesticide to their vegetable production was much more than those who did not apply pesticide to their vegetable production. Pesticides shield crops from unsafe irritations and infections, helping farmers to verify nourishment supply with an effective utilization of common assets (Damalas, 2017). This implies that farm households who produce their vegetable production safely have better chance to participate in vegetables market.

Participation in civic organization: Result in Table 4 show that participating in in civic organization (such as: $i d i r$, iqub, religious activities etc) influence the probability of market participation significantly and positively. The study by Brook (2005) and Antoci et al. (2009) argued that, involving in civic organization/social capital stands for the ability of actors to impervious benefits through advantage of membership in social networks or different social structures, is becoming a essential issue (input) in perception differences in economic outcome. This implies that farm households who participate in any civic organization had more chance to participate in vegetable market than other households which did not have such chance.

Table 4. The Heckman two-step selection regression results of market participation

\begin{tabular}{lllll}
\hline & \multicolumn{2}{l}{ Participation } & \multicolumn{2}{l}{ Level of participation } \\
\cline { 2 - 5 } Variable & Coef. & Std. Err. & Coef. & Std. Err. \\
\hline Sex of household head & 0.22 & 0.202 & $0.96^{* * *}$ & 0.388 \\
Household farm experience & 0.00 & 0.003 & 0.04 & 0.032 \\
Education level of household head & $0.02^{*}$ & 0.011 & -0.04 & 0.028 \\
Frequency of extension contact & 0.02 & 0.021 & 0.04 & 0.059 \\
Land size owned & 0.18 & 0.289 & $1.92^{* * *}$ & 0.658 \\
Amount of credit & 0.00 & 0.000 & 0.00 & 0.000 \\
Family size & 0.00 & 0.013 & 0.04 & 0.032 \\
Distance to market centre & $-0.23^{* * *}$ & 0.073 & -0.26 & 0.171 \\
Distance to major town & -0.02 & 0.038 & -0.09 & 0.094 \\
Distance to farmers training centre & -0.04 & 0.070 & $-0.38^{* * *}$ & 0.147 \\
Access to irrigation & $0.84^{* * *}$ & 0.303 & $1.59^{* * *}$ & 0.283 \\
Off or non farm income & 0.00 & 0.000 & 0.00 & 0.000 \\
Total livestock unit & 0.00 & 0.005 & - &. \\
Total income from cereal crop & 0.00 & 0.000 & 0.00 & 0.000 \\
Application of pesticide & $0.51^{* * *}$ & 0.203 & $0.14 * * *$ & 0.218 \\
Participation to civic organization & $0.58^{* * *}$ & 0.111 & $0.39^{*}$ & 0.223 \\
Constant & $-1.37^{* *}$ & 0.703 & $-2.63^{* * *}$ & 0.645 \\
Lambda $(\lambda)$ & $0.51^{*}$ & 0.284 & & \\
Rho & 1.00 & & & \\
Sigma & 0.51 & & & \\
\hline
\end{tabular}

Note: $* * *, * *$ and $*$ show $1 \%, 5 \%$ and $10 \%$ significance level respectively; Wald $\chi 2(16)=105.07$; Non-crop output market participant observations $=184$; Participant observations $=201$; Probability $>\chi 2=0.000$.

Source: Author's computation from sample survey data (2018).

\subsection{Factors Affecting the Level of Market Participation}

To identify the factors affecting the levels of market participation, OLS regression was estimated in the second stage of Heckman model. The result was presented in Table 4 above. Six variables namely sex of the household head, distance to farmers training centre, land size, access to irrigation, application of pesticide and involving 
any civic organization (social capital) significantly affected the level of the vegetable marketed by farm households.

Sex of the household head: As result of Table 4 indicated this variable affect volume of vegetable sales significantly and positively. Being a male headed augmented the proportion of vegetable sales by 96 percent. The male-headed households are believed to possess strong bargaining power which successively increases the proportion of vegetable sales. Male-headed farm families were bound to settle on market choice than female-headed households. This might be because of the way that female-headed family units are presented to asset limitations like work, capital, and land for vegetable production (Diagne et al. 2013). This implies that, the finding from this study might be because of the fact that the male headed households tend to possess larger output than the female headed households as a results of their higher access to productive inputs.

Land size: This variable significantly and positively affect volume of vegetable marketed at 1 percent significance level. As regression output result of the above table farm households that allocated more land size have more opportunity to supply more vegetable production to market than that allocated less land size. This indicates that, farmers who had more land size could allocate their land partly for food crop production and partly for cash crop production, giving them better a position to supply more marketable product (Maponya et al., 2016; Osmani and Hossain, 2015). The result is in line with the study by (Moono, 2015; Anyango, 2016) which argued that, farmers' that allocated more land size to vegetable product participate in market with more level of production with compare to that allocated less land size.

Access to irrigation: This variable significantly and positively influenced the level of market participation at 1 percent significance level. The positive coefficient of irrigation indicates that, farm households that had access to irrigation produce more vegetable products for the market, as irrigation improves the productivity of vegetable farming. This result was in line with a studies by Maponya et al., 2016; Alwang et al., 2012). This implies that access to irrigation was the physical capital required to meet high value market in the study area. Therefore, farm households who have access to irrigation could supply more vegetable to the market than others.

Distance to farmers training centre: As the result of Table 4, distance from household residence to farmers training centre affect volume of vegetable sales negatively and significantly at 1 percent. This implies that, when walking distance to farmers training centre increase by an hour farm households' vegetable volume of sale was decreased by 38 percent. The result is in line with the study prior expectation (Ramoroka, 2012) found that distance to farmers training centre negatively influences both the decision to participate in markets and the volume of output sold. This implies that, regardless of whether farmers are in zones with great road linkages, the distance from the farmers training centre was in general impact product and market information, in this manner farmers that had further far from the farmers training centre may choose not to take an interest in the market on account of the expenses of transport.

Application of pesticide: This variable affects volume of vegetable sale positively and significantly at 10 percent. This implies that when farm household use pesticide for vegetable production the volume of vegetable supply to the market increased by 14 percent. The intensive use of pesticides had considerably exaggerated productivity of the vegetables (Jeyanthi and Kombairaju 2005). This implies that, household that applied pesticides to vegetable production were secured their production from risky of lose and produced surplus product to supply more vegetable to the market.

Participation in civic organization: As the result of Table 4 indicates that, this variable affects volume of vegetable sales positively and significantly at 1 percent. The result showed that as household engaged to civic organization the level of vegetable supply to market increased by 39 percent. Improving level of supply starts with getting information (awareness) about the market, whether through media advertisement, extension agents, or social networks. This is followed by a careful review of the perceived attributes of the market and the potential benefits and costs of acquiring the market (Mukwevho and Anim, 2014). This implies that household that had involved in any civic organization has good social network and could simply improve his/her level of market participation.

\section{Conclusion and Policy Implications}

The study identifies the factors that determine market participation and the level of market participation of vegetable (tomato and potato). Heckman two-step selection model employed to analyze farm households' vegetable production market participation. In the first stage farm household's decision to participation was significantly influenced by education level of household, distance to market centre, access to irrigation, use of pesticide and participation in civic organization. Furthermore, farm household's level of market participation affected sex of household head, land size owned, distance to farmers training centre, access to irrigation, use of 
pesticide and participate in civic organization.

The results of the probit model revealed that, educational level, distance to the nearest market, access to irrigation, application of pesticide and participation to civic organization were the variables which affect market participation significantly. In addition, the OLS results identified that, sex of household head, land size, distance to farmer training centre, access to irrigation, application to pesticide, and involvement in civic organization significantly influence the level of market participation/ amount of vegetables supplied to the market. The findings imply that support for female households, improving adult based education, participation in civic organization, infrastructure, access to irrigation and improved inputs are a means to increase vegetable production market participation and sales volume in West Shewa, Ethiopia.

\section{Acknowledgements}

The College of Agriculture and Environmental Sciences, Haramaya University, has speed up the entire research process. The authors also are grateful to Ambo University for their cooperation throughout the survey.

\section{References}

Alwang Jeffrey R, Everett B Peterson, and Daniel B Taylor. (2012). Going the Distance: The Impact of Distance to Market on Smallholders Crop and Technology Choices Amy D. MSc. Thesis, Virginia Polytechnic Institute and State University.

Andrew, W. S. (2007). Approaches to Linking Producers to Markets, Food and Agriculture Organization of the United Nations Rome.

Antoci, A., Pier, L. S., \& Paolo, V. (2009). Social Capital in a Homogeneous Society, no. 13661.

Anyango, J. D. (2016). Economic Analysis of Smallholder Farmers' Participation in Domestic High-Value Markets for Indigenous Vegetables in Siaya County, Kenya. MSc. Thesis, University of Nairobi.

Barrett, C. B., Maren, E. B., Marc, F., \& Thomas, F. W. (2011). Smallholder Participation in Agricultural Value Chains: Comparative Evidence from Three Continents. https://doi.org/10.2139/ssrn.1733942

Beneberu, A., Sarah, N., Mulunesh, A. A., \& Tina, B. (2016). Challenges and Prospects of Farm and Non-Farm Livelihood Strategies of Smallholder Farmers in Yayu Biosphere Reserve, Ethiopia. A Qualitative Analysis.

Bezabih, E., Afari-sefa, V., Tesfaye, B. D., \& Milkessa, T. (2015). Characterization and Assessment of Vegetable Production and Marketing Systems in the Humid Tropics of Ethiopia. 54(2), 163-87.

Bogale, T., \& Ayalneh, B. (2005). Technical Efficiency of Resource Use in the Production of Irrigated Potato : A Study of Farmers Using Modern and Traditional Irrigation Schemes in Awi Zone, Ethiopia. Journal of Agriculture and Rural Development in the Tropics and Subtropics, 106(1), 59-70.

Brook, K. (2005). Labour Market Participation: The Influence of Social Capital. no: 113-23.

Byron. (2014). Determinants of Soybean Market Participation by Smallholder Farmers in Zimbabwe. Journal of Development and Agricultural Economics, 6(2), 49-58. https://doi.org/10.5897/JDAE2013.0446.

Chala, H., \& Chalchisa, F. (2017). Determinants of Market Outlet Choice for Major Vegetables Crop: Evidence from Smallholder Farmers ' of Ambo and Toke-Kutaye Districts, West Shewa. Journal of Economics and Sustainable Development, 4(2), 161-69.

Chittora, A., Vinita, B., \& Vishal, J. (2017). Marketing and Production of Fruits and Vegetables in India Marketing and Production of Fruits and Vegetables in India. International Journal of Current Microbiology and Applied Sciences, 6(9), 2896-2907. https://doi.org/10.20546/ijcmas.2017.609.356.

Cochrane, L., \& Yeshtila, W. B. (2018). Average Crop Yield (2001-2017) in Ethiopia: Trends at National, Regional and Zonal Levels. Data in Brief, 16, 1025-1033. https://doi.org/10.1016/j.dib.2017.12.039

CSA. (2016). The Federal Democratic Republic of Ethiopia Central Statistical Agency Report on Area and Production of Major Crops.

Damalas, C. A. (2017). Farmers' Training on Pesticide Use Is Associated with Elevated Safety Behavior. Toxics, 5(3), 19. https://doi.org/10.3390/toxics5030019.

Diagne A, Awoyemi, T. T., \& Diagne, A. (2013). Agricultural Technology Adoption, Market Participation and Rural Farming Households' Welfare in Nigeria Department of Agricultural Economics. University of Ibadan, Nigeria Africa Rice Centre, Cotonou, Benin Republic 17- Agricultural Technology Adop. 
Fanos, T. (2015). A Review on Production Status and Consumption Pattern of Vegetable in Ethiopia. Journal of Biology, Agriculture and Healthcare, 5(21), 82-93.

FAO. (2016). How Does Agricultural Trade Impact Food Security ?. no. 17.

Frederick I. (1983). The Application of Tobit and Probit Estimation to Aggregate Data.

Fried, H. O., Lovell, C. A. K., \& Shelton, S. S. (2004). Efficiency and Productivity. 1-106.

Fufa, N. (2017). Opportunity, Problems and Production Status of Vegetables in Ethiopia: A Review. 4(2), 1-13.

Gani, B. S., \& Adeoti, A. I. (2011). Analysis of Market Participation and Rural Poverty among Farmers in Northern Part of Taraba State, Nigeria. Journal of Economics, 2(1), 23-36.

Getachew, M., \& Bamlak, A. (2014). Analysis of Technical Efficiency of Small Holder Maize Growing Farmers Of Horo Guduru Wollega Zone, Ethiopia: A Stochastic Frontier Approach. Science, Technology and Arts Research Journal, 7522(3), 204-12.

Hector, K. (2012). Participation and Utilisation of Formal Vegetable Markets By Smallholder Farmers in Limpopo: A Tobit Ii Approach.

Hjalmarsson, L., \& Forsund, F. R. (1978). Generalized Farrell Measures of Efriciency: An Application to Milk Processing in Swedish Dairy Plants. Economic Journal, Royal Economic Society, 89(354), 294-315.

Imai, K. S., \& Gaiha, R. (2012). Agricultural Supply Response and Smallholders Market Participation - the Case of Cambodia.

IMF. (2015). The Federal Democratic Republic of Ethiopia Report; and Statement By The Executive Director. no. 15.

Jeyanthi, H., \& Kombairaju, S. (2005). Pesticide Use in Vegetable Crops: Frequency , Intensity and Determinant Factors. Agricultural Economics Research Review, 18(December), 209-21.

Maponya, P., Venter, S., Du, P. C., and Modise, S. (2016). An Evaluation of Market Participation Challenges of An Evaluation of Market Participation Challenges of Small Holder Farmers in Zululand District, Kwazulu Natal, South Africa.

Maponya, P., Venter, S., Du, P. C., Modise, S., \& Van Den, H. (2016). An Evaluation of Market Participation Challenges of Small Holder Farmers in Zululand District, Kwazulu Natal, South Africa. African Journal of Business and Economic Research. 11(1), 117-42.

Masuku, B. B., Masuku, M. B., \& Belete, A. (2014). Economic Efficiency of Smallholder Dairy Farmers in Swaziland: An Application of the Profit Function. Journal of Agricultural Studies, 2(2). https://doi.org/10.5296/jas.v2i2.6046

Mohamedl, A. (2014). Determinants of Participation in Milk Marketing of Small Holders in Jijiga Woreda, Ethiopia. MSc. thesis Mekelle University.

Montalbano, P., Pietrelli, R., \& Salvatici, L. (2017). Market Chain Participation and Food Security: The Case of the Ugandan Maize Farmers. https://doi.org/10.13140/RG.2.2.11751.65442.

Mukwevho, R., \& Anim, F. D. K. (2014). Factors Affecting Small Scale Farmers in Accessing Markets : A Case Study of Cabbage Producers in the Vhembe District , Limpopo Province of South Africa. Journal of Human Ecology, 48(2), 219-25. https://doi.org/10.1080/09709274.2014.11906791

Musah, A. B., Osei-asare, Y. B., \& Wayo, S. (2014). Market Participation of Smallholder Maize Farmers in the Upper West Region of Ghana. African Journal of Agricultural Research, 9(31), 2427-35. https://doi.org/10.5897/AJAR2014.8545.

Nakasone, E. (2014). The Role of Price Information in Agricultural Markets : Experimental Evidence The Role of Price Information in Agricultural Markets: Experimental Evidence from Rural Peru. no. December 2013.

Omiti, J. M., \& Ellen, M. (2009). Factors Influencing the Intensity of Market Participation by Smallholder Farmers: A Case Study of Rural and Peri-Urban Areas of Kenya. African Journal of Agricultural \& Resource Economics, 3(1), 57-82.

Osmani, A. G., \& Elias, H. (2015). Market Participation Decision of Smallholder Farmers and its Determinants in Bangladesh. Economics of Agriculture, 3(62).

Pierre, J., Kamanzi, M., \& Antoine, K. (2017). Analysis of Factors Influencing Market Participation of Smallholder Bean Farmers in Nyanza District of Southern Province, Rwanda. Journal of Agricultural 
Science, 9(11), 99-111. https://doi.org/10.5539/jas.v9n11p99.

Wickramasinghe, B. U., Norah, O., Arnold, D. P., \& Joshua, R. (2009). Market Participation of Smallholder Agricultural Households in Papua New Guinea.

\section{Copyrights}

Copyright for this article is retained by the author(s), with first publication rights granted to the journal.

This is an open-access article distributed under the terms and conditions of the Creative Commons Attribution license (http://creativecommons.org/licenses/by/3.0/). 